\title{
Hybridizing moral expressivism and moral error theory
}

Toby Svoboda

Fairfield University, tsvoboda@fairfield.edu

Follow this and additional works at: https://digitalcommons.fairfield.edu/philosophy-facultypubs Copyright 2011 Springer. A post print has been archived with permission from the copyright holder. The final publication is available at Springer via http://dx.doi.org/10.1007/ s10790-011-9259-z

\section{Peer Reviewed}

\section{Repository Citation}

Svoboda, Toby, "Hybridizing moral expressivism and moral error theory" (2011). Philosophy Faculty Publications. 29.

https://digitalcommons.fairfield.edu/philosophy-facultypubs/29

\section{Published Citation}

Svoboda, Toby. "Hybridizing moral expressivism and moral error theory." The Journal of Value Inquiry 45.1 (2011): 37-48. 10.1007/s10790-011-9259-z

This item has been accepted for inclusion in DigitalCommons@Fairfield by an authorized administrator of DigitalCommons@Fairfield. It is brought to you by DigitalCommons@Fairfield with permission from the rightsholder(s) and is protected by copyright and/or related rights. You are free to use this item in any way that is permitted by the copyright and related rights legislation that applies to your use. For other uses, you need to obtain permission from the rights-holder(s) directly, unless additional rights are indicated by a Creative Commons license in the record and/or on the work itself. For more information, please contact digitalcommons@fairfield.edu. 


\section{Hybridizing Moral Expressivism and Moral Error Theory}

(Post-Print Version)

Toby Svoboda, Fairfield University

Published in The Journal of Value Inquiry 45:1 (2011): 37-48 ${ }^{1}$

\section{Introduction}

Some philosophers recently have developed hybrid meta-ethical theories by merging elements of both expressivism and cognitivism. ${ }^{1}$ Such hybrid theorists combine the expressivist thesis that moral utterances are neither true nor false because they are used to express attitudes with the cognitivist thesis that moral utterances are true or false because they are used to express beliefs. Hybrid theories advanced so far in the literature typically include success-theoretic rather than error-theoretic versions of cognitivism. Current hybrid theorists hold both that moral utterances are used to express attitudes and beliefs, and that some of these expressed beliefs are true. However, philosophers should also consider a hybrid theory that includes elements of both moral expressivism and moral error theory. Although such a hybrid expressivist-error theory has not previously been presented or defended in the literature, it is theoretically preferable to both pure error theory and pure expressivism. Accepting such a hybrid theory has two advantages over pure expressivism, because hybrid theorists both can more plausibly explain certain aspects of moral discourse and can avoid the Frege-Geach problem. Accepting such a hybrid expressivist-error theory has three advantages over pure error theory, because hybrid theorists can more plausibly explain certain aspects of moral discourse, they can less controversially account for moral motivation, and they do not implausibly treat all of

\footnotetext{
${ }^{1}$ The final version is available at http://link.springer.com/article/10.1007\%2Fs10790-011-9259-z?LI=true.
} 
moral discourse as deeply mistaken. Accordingly, such a hybrid theory should be more attractive to philosophers who are skeptical about success-theoretic cognitivism than either pure expressivism or pure error theory.

Let us suppose that an individual is deeply skeptical about moral facts and moral truth. Such a person should thereby be deeply skeptical about moral realism and moral constructivism, because accepting either theory commits her to holding that some moral utterances and judgments are true in virtue of moral facts. Nor will such a skeptic be satisfied with recent hybrid meta-ethical theories that include elements of both expressivism and success-theoretic cognitivism, since this implies accepting moral truth and facts. Traditionally, philosophers who are skeptical about moral facts have turned to moral expressivism or moral error theory. Proponents of both these theories agree that no moral utterance is true, although they adopt this view for different reasons. Expressivists hold that moral utterances are not used to describe putative moral facts but rather are used to express attitudes of the speaker. ${ }^{2}$ On their view, there is no true moral utterance because every moral utterance is neither true nor false. Conversely, error theorists hold that moral utterances are used to describe putative moral facts but that there are no moral facts. ${ }^{3}$ On their view, since moral utterances are used to express beliefs about entities, properties, or relations that do not exist, there is no true moral utterance because, as John Mackie puts it, moral utterances are "all false.” Accordingly, expressivists and error theorists agree that there are no moral facts, but they disagree about the nature of moral utterance and judgment. Each theory is plausible in some respects, but expressivists and error theorists both face problems of their own. Accordingly, philosophers who are both 
skeptical about moral truth and unsatisfied with expressivism or error theory should consider a neglected alternative, a hybrid of expressivism and error theory.

Such a hybrid expressivist-error theorist treats every moral utterance as either an expression of a speaker's attitude or an expression of a false belief. For the sake of simplicity, let us assume that any moral utterance is used to express either an attitude or a belief, leaving aside the interesting question of whether a single moral utterance can be used to express both an attitude and a belief. According to a hybrid theorist, some but not all moral utterances are used to express the attitudes of speakers, and all such utterances are neither true nor false; some but not all moral utterances are used to express the beliefs of speakers, and all such beliefs are false; and no moral utterance is used to express a true belief of a speaker. An expressivist-error theorist thus holds that there are no moral facts that could make moral utterances true, but she allows that some moral utterances are used to express attitudes that are neither true nor false. Like pure expressivists, a hybrid theorist holds that some moral utterances are used express attitudes of the speaker. Like pure error theorists, a hybrid theorist holds that some moral utterances are used to express false beliefs about putative moral facts. Like both expressivists and error theorists, a hybrid theorist rejects the existence of moral facts and thus denies that any moral utterance is true.

A hybrid expressivist-error theory is more plausible than either pure expressivism or pure error theory, because an expressivist-error theorist can avoid at least two difficulties with pure expressivism and at least three difficulties with pure error theory. First, pure expressivists have trouble accounting for the fact that some moral utterances seem to be used to express beliefs of speakers rather than attitudes of speakers. Second, 
pure expressivists must adopt theoretically complex measures in order to solve the FregeGeach problem. Third, pure error theorists have difficulty accounting for the fact that some moral utterances seem to be used to express attitudes of speakers rather than beliefs about putative moral facts. Fourth, pure error theorists can account for moral motivation only by appealing to the controversial claim that beliefs can motivate action. Fifth, accepting pure error theory has the implausible result of attributing systematic error to all of moral discourse. Accepting a hybrid expressivist-error theory alleviates all five of these difficulties. Since it has these advantages over both pure expressivism and pure error theory, such a hybrid theory should be considered seriously by philosophers who are skeptical about moral truth and moral facts.

\section{Moral Utterances as Expressions Beliefs}

Taking the first difficulty with pure expressivism, some moral utterances seem to be used to express beliefs rather than attitudes. For example, if a speaker says, "It is true that murder is wrong,” and all evidence suggests that the speaker is being sincere, then it seems that the moral utterance is used to express a belief in the proposition that murder is wrong. Pure expressivists claim that appearances are misleading in this case and that the utterance really is used to express only an attitude of the speaker, such as the speaker's disapproval of murder. However, this claim is implausible. As Russ Shafer-Landau argues, the speaker's moral utterance has the grammatical form of an assertion. ${ }^{5}$ Furthermore, the speaker attributes truth to the utterance, and the available evidence suggests that the speaker is sincere. If the speaker in this example is actually expressing an attitude and not a belief, it is very strange that he does so via an utterance that, given 
its grammar and the other contextual evidence, very much looks like an expression of belief. Accordingly, it is more plausible to treat this moral utterance as an expression of a belief rather than an expression of an attitude. Since speakers commonly do make utterances of this sort, pure expressivists must give an implausible interpretation of such aspects of moral discourse.

This consideration does not serve to refute pure expressivism but only indicates a disadvantage for the pure expressivist with respect to her cognitivist rivals. While it is possible that the utterance, "It is true that murder is wrong," is actually an expression of an attitude in disguise, it is surely more plausible to interpret it according to cognitivist lights. Expressivist-error theorists can do just this, taking such moral utterances at face value and treating them as expressions of beliefs. Although hybrid theorists reject that any such moral belief is true, they can accept that some moral utterances nonetheless are used to express false beliefs, and this allows them to give a more plausible account of moral utterances that seem to be cognitivist in nature. Since this option is available for an expressivist-error theorist but not for a pure expressivist, a hybrid theory is more plausible than pure expressivism in this respect. All else being equal, this provides grounds to accept a hybrid theory over pure expressivism. It is important to stress, however, that such a hybrid theory treats only some moral utterances as expressions of false beliefs. Expressivist-error theory is thus distinct from pure error theory, whose proponents treat all moral utterances as expressions of false beliefs.

Pure expressivists could attempt to alleviate this first difficulty with pure expressivism by appealing to a minimalist account of truth. On this account, truth is not a substantive property of utterances because there is nothing more to truth than the schema, 
“p” is true if and only if p. ${ }^{6}$ Hence, pure expressivists might explain the assertoric grammar and truth-predication of various moral utterances via minimalist lights, such that an expressivist interpretation is more plausible. For example, Simon Blackburn writes that "minimalism about truth allows us to end up saying 'It is true that kindness is good'. For this means no more than that kindness is good, an attitude we may properly want to express."7 Since minimalists hold that the truth-predication in this utterance adds nothing to the expression of an attitude in favor of kindness, minimalists can hold consistently that the utterance is used to express an attitude rather than a belief. It is likewise with the utterance, "It is true that murder is wrong," which minimalist expressivists can interpret as being used to express nothing more than a disapproving attitude of murder.

There are, however, at least two disadvantages to this minimalist approach. First, it will be acceptable only to philosophers who also accept a minimalist account of truth, to which there are a variety of objections. ${ }^{8}$ Since proponents of a hybrid expressivisterror theory can but need not accept minimalism, such a hybrid theory is a viable option for philosophers who do not accept minimalism, whereas minimalist expressivism is not a viable option for them. There is nothing about a hybrid expressivist-error theory that requires its proponents either to accept or to reject minimalism. Such a hybrid theory is consistent with either position. Hence, expressivist-error theorists can appeal to a wider spectrum of philosophers than minimalist expressivists. This is not a refutation of minimalist expressivism, since it might be the case that philosophers should accept minimalism. However, minimalist expressivists have the disadvantage of succeeding or failing along with minimalists about truth, whereas expressivist-error theory can be attractive both to philosophers who accept and do not accept minimalism. 
The second disadvantage for minimalist expressivists is that, even if the objections to minimalism in general can be answered, they still face what James Dreier calls the problem of creeping minimalism, or the danger that minimalist expressivism will prove indistinguishable from its cognitivist rivals. ${ }^{9}$ This is because minimalism about truth seems to lead to minimalism about belief. Dreier writes, “Any state of mind expressed by a declarative sentence, $\mathrm{S}$, automatically, minimalistically counts as a belief that S. There needn’t be much of anything that ties together all of the states called 'belief', nothing over and above their being those states expressed by declarative sentences." ${ }^{10}$ For example, if an expressivist holds that the moral utterance, "Murder is wrong," is true in a minimalistic sense, it is difficult to see how he can avoid holding that the speaker also believes that murder is wrong in a minimalistic sense. However, if an expressivist accepts that moral utterances are used to express beliefs, then the distinction between expressivism and cognitivism seems to be effaced, since in that case expressivists will accept the central cognitivist thesis that moral utterances are expressions of beliefs.

A hybrid expressivist-error theorist has the advantage of being able to preserve the distinction between expressivism and cognitivism, because she can treat some moral utterances as expressions of attitudes rather than beliefs while treating other moral utterances as expressions of beliefs rather than attitudes. Although such a hybrid theorist combines elements of both expressivist and cognitivist theories, she recognizes a distinction between expressions of beliefs and expressions of attitudes. This allows hybrid theorists to avoid the problem of creeping minimalism, because they need not treat 
expressions of attitudes as minimalistic beliefs. Hence, all else being equal, a hybrid expressivist-error theory is theoretically preferable to minimalist expressivism.

\section{The Frege-Geach Problem}

Second, an expressivist-error theorist can deal with the Frege-Geach problem in a simpler fashion than a pure expressivist. ${ }^{11}$ Let us consider Peter Geach’s example of what he calls moral reasoning: "If doing a thing is bad, getting your little brother to do it is bad. Tormenting the cat is bad. Ergo, getting your little brother to torment the cat is bad.”"12 This seems to be a valid modus ponens argument in which the third utterance follows from the first two. If an individual sincerely presents this argument, she seems to be using moral utterances to express beliefs about two propositions whose truth would logically guarantee the truth of a third proposition. Furthermore, in keeping with a thesis first presented by Gottlob Frege that the meaning of an utterance is the same in both asserted and unasserted contexts, all three utterances seem to be used to express propositions even if the speaker is not using the utterances assertorically. ${ }^{13}$ For example, even if an actor in a play sequentially speaks these three utterances, the first two nonetheless seem to be expressions of propositions, and the third utterance seems to be an expression of a proposition that is logically entailed by the first two. However, if pure expressivism is true, the utterances in Geach's example are not expressions of beliefs in propositions. Accordingly, these utterances cannot figure as premises in a valid argument in classical logic and hence cannot guarantee the truth of the conclusion, because none of the utterances has a truth value. But Geach’s example nonetheless seems to be a valid argument. The problem for pure expressivists is to explain how valid moral reasoning 
seems to occur despite the fact that moral utterances are not used to express beliefs about propositions.

One option is to deny that Geach’s example and others like it really are cases of valid moral reasoning. According to this strategy, the third utterance in Geach's example does not follow from the first two. This is because no moral utterance is used to express a belief about a proposition, and only an utterance that is used to express a belief about a proposition can serve as a component of a valid argument. Instead, each of these moral utterances is used to express an attitude, and none of them has any logical relation to the others. But this extreme strategy has the implausible result that someone can hold the attitudes that the first two utterances in Geach's example are used to express without thereby having a reason to hold the attitude that the third utterance is used to express. Accordingly, someone can disapprove of getting her brother to do something of which she disapproves, and she can disapprove of tormenting the cat, yet not have a reason to disapprove of getting her brother to torment the cat. Few expressivists are willing to accept this result, because it seems that the disapproval that the third utterance is used to express follows from the disapproval that the first two utterances are used to express.

Another option for expressivists to deal with apparent examples of valid moral reasoning is to develop alternative logics that permit inferences between attitudes rather than propositions. Expressivists such as Blackburn have pursued this strategy, developing a logic of attitudes that mimics logics of propositions. ${ }^{14}$ Blackburn argues that being consistent requires an individual to hold certain attitudes in virtue of other attitudes he also holds. ${ }^{15}$ According to this account, some attitudes follow from others in the sense that it would be inconsistent to fail to hold some attitudes given others. Reconsidering 
Geach’s example, the moral utterance, “If doing a thing is bad, getting your little brother to do it is bad," is used to express disapproval of getting a person's own brother to do something of which that person disapproves. The moral utterance, "Tormenting the cat is bad,” is used to express disapproval of tormenting the cat. If a person holds all the attitudes just enumerated, then disapproval of getting that person's own brother to torment the cat follows from the other attitudes. The moral utterance, "Hence, getting your little brother to torment the cat is bad” is used to express this conclusion. According to Blackburn, being consistent requires a person to hold this last attitude in virtue of the other attitudes she already holds. If a person disapproves of making her brother do something of which she disapproves, and if she disapproves of tormenting the cat, then by consistency she should also disapprove of making her brother torment the cat. Hence, according to Blackburn's account, the attitude that the third utterance is used to express in a sense follows from the attitudes that the first two utterances are used to express.

Such a logic of attitudes might account for cases of moral reasoning that seem valid, but it is simpler to treat such cases as the logically valid arguments they appear to be. Hybrid expressivist-error theorists are able to do this by treating some but not all moral utterances as expressions of beliefs in propositions, such as those in Geach's example. Such a hybrid theory thus provides a simpler account of moral reasoning by treating Geach’s example as a valid argument composed of propositions. Each of the moral utterances in this example is used to express a belief in a proposition, and it is impossible for the first two propositions to be true while the third proposition is false. As a solution to the Frege-Geach problem, Blackburn's account is more theoretically complex than a hybrid expressivist-error theory, because his account treats the utterances 
in Geach's example as covert expressions of attitudes, despite the fact that they appear to be expressions of beliefs that function in a valid modus ponens argument. This consideration does not serve to refute Blackburn's logic of attitudes as an account of apparently valid moral reasoning. Indeed, Blackburn himself is unconvinced by this consideration. ${ }^{16}$ Nonetheless, it does serve to show that expressivist-error theory is preferable on this score. Proponents of expressivist-error theory simply can accept the apparent validity of some cases of moral reasoning and thus avoid the Frege-Geach problem in the first place. All else being equal, this is a reason to prefer the expressivisterror theory.

\section{Moral Utterances as Expressions of Attitudes}

The first advantage of a hybrid expressivist-error theory over pure error theory is that pure error theorists treat all moral utterances as expressions of false beliefs and thus have difficulty accounting for moral utterances that seem to be used to express attitudes rather than beliefs. Let us consider a relative of a solider killed in a military conflict who sincerely shouts at a war protest, “Down with war!” This moral utterance seems to be used to express disapproval of war rather than any belief about war, both because the utterance has the grammatical form of an imperative rather than an assertion and because the utterance is spoken sincerely by someone who has an especially strong reason to disapprove of war. Since expressions of attitudes are neither true nor false, this is a counter-example to the pure error theorist's thesis that all moral utterances are used to express false beliefs. To retain their thesis, pure error theorists must claim implausibly that appearances are misleading in this case and that "Down with war!" really is used to 
expresses a belief, for example that war is wrong. This is implausible because the grammar of the utterance and the contextual evidence suggest that the utterance is used to express a disapproving attitude toward war rather than a belief.

However, just as pure expressivism is not refuted by appealing to utterances that seem to be used to express beliefs, pure error theory is not refuted by appealing to utterances that seem to be used to express attitudes. The point is simply that the pure error theorist is at a disadvantage relative to his expressivist competitors when it comes to accounting for utterances like “Down with war," because a pure error theorist must interpret such utterances implausibly as expressions of false beliefs. An expressivist-error theorist can avoid this implausibility by allowing that such moral utterances are neither true nor false, because they are used to express attitudes rather than beliefs. Accordingly, a hybrid theory is more plausible than pure error theory on this score. All else being equal, this provides grounds to accept a hybrid theory over pure error theory.

A potential objection is that pure error theorists need not concur with Mackie that all moral utterances are used to express false beliefs. ${ }^{17}$ Instead, an error theorist could hold both that some but not all moral utterances are used to express false beliefs and that no moral utterance is used to express a true belief. Given this formulation, an error theorist can eschew the implausible cognitivist interpretation of “Down with war!” as an expression of a belief. Yet this would leave many moral utterances unexplained because it would not offer an interpretation of moral utterances that do not seem to be used to express beliefs. If an error theorist is not to ignore such moral utterances, and if he is not to treat them implausibly as disguised expressions of beliefs, then he must offer some account of them that is not purely cognitivist. Error theorists typically do not offer this 
account, but a hybrid theorist can do so by offering an expressivist interpretation of any moral utterance that does not seem to express a belief. Hence, even granting that error theorists could avoid holding that all moral utterances are used to express false beliefs, hybrid theorists still have the advantage of offering an account of the moral utterances that do not fit well into a cognitivist interpretation.

\section{Moral Motivation}

The second advantage of a hybrid expressivist-error theory is that, like cognitivists in general, pure error theorists have difficulty accounting for moral motivation. It is not immediately clear how beliefs can motivate agents to act in the way that moral judgments do. While it is obvious that attitudes can be motivational, it is not obvious that beliefs can be motivational. Accordingly, following Hume, expressivists can argue that their theory easily explains the fact that agents are at least sometimes motivated by their moral judgments, since these judgments are used to express attitudes and thus are tied to an individuals desires about how to act. ${ }^{18}$ Since pure error theorists hold that sincere moral judgments and utterances are used to express false beliefs, they must explain how such beliefs can motivate agents to act. Since it is much less clear that beliefs can motivate someone to act than that attitudes can motivate someone to act, pure expressivists have an easier time explaining the evident fact that moral judgments are at least sometimes motivational, which makes expressivism theoretically preferable to error theory on this point.

Hybrid expressivist-error theorists can follow the pure expressivist in this regard, treating moral judgments that motivate agents to act as attitudes rather than beliefs and 
treating any accompanying moral utterances as expressions of attitudes rather than expressions of beliefs. Unlike pure error theorists and cognitivists in general, proponents of a hybrid theory need not meet the difficult challenge of showing that beliefs can motivate individuals to act, since hybrid theorists can treat all motivating moral judgments as attitudes. This does not refute pure error theory, but it does show that expressivist-error theory is theoretically preferable on this point. All else being equal, this is a reason to prefer a hybrid theory over pure error theory.

A potential objection to this argument is that cognitivists can offer convincing, anti-Humean arguments that beliefs can motivate agents to act. Shafer-Landau holds that anti-Humeanism about motivation has a "phenomenological appeal” in the case of an individual who acts while mistakenly believing she has a certain desire. He uses the example of a person who believes she attends law school because she desires to be a lawyer but later discovers that she never in fact desired to be a lawyer. ${ }^{19}$ This individual's motivation to attend law school cannot be explained by her desire to be a lawyer, since she actually lacked this desire all along. Shafer-Landau concludes, “The natural, and simplest, explanation of these sorts of situations is that mistaken beliefs alone are doing the motivating work." ${ }^{20}$ On this account, an individual can act on the basis of a mistaken belief that she has a certain desire, which implies that beliefs can motivate. If this is correct, then perhaps cognitivists can account for moral motivation in terms of beliefs rather than attitudes.

However, Shafer-Landau also notes that proponents of motivational Humeanism always can claim that agents in such examples are motivated to act because they care about something, where such caring is understood in terms of the attitudes of the agent. 
For example, an individual might attend law school while mistakenly believing she desires to be a lawyer, but her motivation is not that mistaken belief but rather consists of her caring about something, such as the approval of her lawyer parents. Shafer-Landau attempts to counter this defense of Humeanism by offering a cognitivists interpretation of caring, but this is a controversial matter. ${ }^{21}$

A hybrid expressivist-error theory is attractive on this score, because its proponents can treat all motivating moral judgments as attitudes. Accordingly, hybrid theorists need not rely on the controversial claim that moral beliefs can motivate agents to act. These considerations refute neither success-theoretic nor error-theoretic cognitivism. However, since the ability of beliefs to motivate action is in question, whereas the ability of attitudes to motivate action is not in question, an expressivist account of moral motivation is less controversial than a cognitivist account of moral motivation. All else being equal, a theory whose proponents account for moral motivation in terms of attitudes should be attractive to more philosophers than a theory whose proponents account for moral motivation in terms of beliefs. Thus, at least on this matter, a hybrid expressivist-error theory seems theoretically preferable to pure error theory.

\section{Radical Error}

The third difficult with pure error theory is that its proponents must implausibly attribute widespread error to all of moral discourse. Mackie, who first defended a moral error theory explicitly, treats all moral utterances as expressions of false beliefs, while the contemporary error theorist, Richard Joyce, treats all moral utterances as untrue assertions. $^{22}$ On both accounts, moral discourse is radically mistaken. This result is not 
absurd, nor does it count as a refutation of moral error theory. Some entire discourses are radically mistaken, such as phlogiston discourse. ${ }^{23}$ However, it is implausible to hold that moral discourse is radically mistaken, because it is improbable that a radically mistaken kind of discourse would endure for millennia among various cultures the way that moral discourse has. If the purpose of any moral utterance is to be an expression of a true belief about a putative moral fact, and if every such utterance is false, then every moral utterance is a failure. If this is the case, then it is odd that moral utterances should continue to receive such widespread use rather than, like utterances used to express belief in phlogiston, being recognized as components of a fundamentally failed discourse. While this oddity does not refute pure error theory, it is a challenge for pure error theorists to explain how such a fundamentally flawed kind of discourse has been and continues to be such a widespread feature of human discourse.

Mackie attempts to meet this challenge by appealing to various patterns of objectification, whereby certain subjective states are mistakenly treated as objective moral facts. ${ }^{24}$ For example, an individual's belief in some alleged moral fact can be explained as a projection of her attitudes or desires, where such attitudes or desires are objectified and believed mistakenly to be mind-independent properties. According to Mackie, there are understandable motives for these patterns of objectification, such as the desire for morality to be used to regulate human interactions, sometimes in ways contrary to the inclinations of individuals. ${ }^{25}$ The objectification of subjective states, although it leads to the expression of false beliefs, grants an appearance of authority to morality and thus serves a useful social function. This is one way for an error theorist to account for 
why moral discourse should persist so stubbornly despite the fact that it is radically mistaken.

Alternatively, hybrid expressivist-error theorists do not attribute systematic error to moral discourse, because they can treat some, perhaps many, moral utterances as neither true nor false. This is consistent with the error-theoretic component of a hybrid theory, because hybrid theorists treat only some but not all moral utterances as expressions of false beliefs. Since some moral utterances are used to express attitudes, and since attitudes are neither true nor false, such utterances cannot be mistaken. This serves to vindicate parts of moral discourse. Hence, hybrid theorists need not explain why a fundamentally flawed discourse receives such widespread adoption. While hybrid theorists deny that any moral utterances are true and accept that some moral utterances are false, they allow that some moral utterances succeed in their purpose of being used to express attitudes. It is easier to understand how such a discourse could be so widespread and long-lived, since moral utterances sometimes are successful at performing their function as expressions of attitudes. This is an advantage over pure error theory, whose proponents must look for additional explanations of why a radically mistaken kind of discourse should endure. The fact that hybrid theorists need not offer these additional explanations makes it simpler and thus theoretically preferable to pure error theory.

\section{Uniting Expressivism and Error Theory}

One qualm with the expressivist-error theory sketched above is that it does not include a guaranteed procedure to determine which moral utterances are used to express beliefs and which are used to express attitudes. Some moral utterances clearly seem to do one rather 
than the other, but this is not obvious in every case. For example, the utterance, "Tom ought not to murder anyone,” might be either an expression of one’s disapproval of Tom murdering anyone or an expression of the belief that Tom murdering anyone is wrong. In such cases, it is not obvious whether the utterance should be given an expressivist or error-theoretic treatment. Perhaps a procedure can be found to delineate clearly whether an utterance is used to express a belief or an attitude, or perhaps the distinction is inherently vague. However, the fact that a hybrid theorist cannot determine the nature of all particular moral utterances is not an objection to that theory itself, because this metaethical theory is meant only to offer a general account the nature of moral utterances. Furthermore, the question of whether a particular moral utterance in fact is used to express a belief or an attitude is an empirical issue. Accordingly, inquirers can investigate the matter empirically, such as by asking questions of a speaker to determine the nature of his moral utterance and paying attention to contextual evidence that could help determine whether that utterance is used to express a belief or an attitude.

A second qualm with a hybrid expressivist-error theory is that its proponents do not solve any problem that is not soluble be either pure error theorists or pure expressivists. For example, a hybrid theorist deals with the Frege-Geach problem by appealing to the insights of error theorists, and she explains moral motivation by appealing to the insights of expressivists. Neither of these solutions is unique to a hybrid expressivist-error theory. However, the ability of proponents of such a hybrid theory to countenance the insights of both error theorists and expressivists is unique, and it allows hybrid theorists to solve more problems than either pure error theorists or pure expressivists. For example, while pure expressivists can explain moral motivation with 
relative ease, it is more difficult on their theory to deal with the Frege-Geach problem. Conversely, while pure error theorists can deal with the Frege-Geach problem with relative ease, it is more difficult on their theory to explain moral motivation. The fact that hybrid theorists can appeal consistently to both an error-theoretical solution to the FregeGeach problem and an expressivist account of moral motivation, as well as other elements of both error theory and expressivism, is sufficient to make it a unique and attractive option for philosophers who are skeptical concerning moral facts and truth.

A third and final qualm with a hybrid expressivist-error theory concerns questions about its unity. Since hybrid theorists borrow from both pure error theory and pure expressivism, there is a risk of applying the error-theoretic and expressivist components of a hybrid theory in an unprincipled fashion, such as by applying whichever component is convenient in a given case. This would be little better than alternately applying pure error theory and pure expressivism haphazardly. It is thus reasonable to worry that a hybrid theory is nothing more than a disjointed aggregation of pure error theory and pure expressivism rather than a unified theory.

However, the risk of unprincipled application of a hybrid theory’s components can be avoided by paying attention to the nature of particular moral utterances. A particular moral utterance requires error-theoretic treatment if and only if that utterance is used to express a belief. A particular moral utterance requires expressivist treatment if and only if that utterance is used to express an attitude. Given these two principles, a hybrid theorist does not haphazardly apply the error-theoretic or expressivist components of her theory, since which component is appropriate to apply is constrained by the nature of the moral utterance under consideration. Since such a hybrid theorist recognizes that 
some moral utterances are used to express beliefs whereas other moral utterances are used to express attitudes, the unity of a hybrid expressivist-error theory is secure by the principles whereby its error-theoretic and expressivist components are respectively applied to moral utterances used to express beliefs and moral utterances used to express attitudes.

An expressivist-error theory is preferable to pure expressivism, because hybrid theorists can account more plausibly for moral utterances that seem to be used to express beliefs rather than attitudes, and they can avoid the Frege-Geach problem without resorting to complex measures. A hybrid theory is preferable to pure error theory, because hybrid theorists can account more plausibly for moral utterances that seem to be used to express attitudes rather than beliefs, they can explain moral motivation straightforwardly in terms of attitudes rather than beliefs, and they avoid attributing systematic error to the whole of moral discourse. For philosophers who are sympathetic to the view that no moral utterance is true, expressivist-error theory is more attractive than either expressivism or error theory on its own. ${ }^{26}$

Notes.

1. See Daniel Boisvert, "Expressive-Assertivism,” Pacific Philosophical Quarterly, Vol. 89, No. 2 (2008): pp. 169-203; David Copp, “Realist Expressivism: A Neglected Option for Moral Realism,” Social Philosophy and Policy, Vol. 18, No. 2 (2001): pp. 1-43; Michael Ridge, “Ecumenical Expressivism: Finessing Frege,” Ethics Vol. 116, No. 2 (2006): pp. 302-336; Ridge, “Ecumenical 
Expressivism: The Best of Both Worlds?” in Rush Shafer-Landau, ed., Oxford Studies in Metaethics, Vol. 2 (2007): pp. 51-76; Mark Schroeder, “Hybrid Expressivism: Virtues and Vices,” Ethics, Vol. 119, No. 2 (2009): pp. 257-309.

2. See A. J. Ayer, Language, Truth and Logic (Mineola, N.Y: Dover, 1952), pp.

102-114; Simon Blackburn, “Attitudes and Contents,” in Essays in QuasiRealism (Oxford: Oxford University Press, 1993); Blackburn, Spreading the Word (Oxford: Clarendon Press, 1984); Allan Gibbard, Wise Choices, Apt Feelings: A Theory of Normative Judgment (Cambridge: Harvard University Press, 1990).

3. See Richard Joyce, The Myth of Morality (Cambridge: Cambridge University Press, 2002); J. L. Mackie, Ethics: Inventing Right and Wrong (London: Penguin, 1977).

4. $\quad$ Mackie, op. cit., p. 35.

5. See Russ Shafer-Landau, Moral Realism (Oxford: Oxford University Press, 2003), pp. 23-24.

6. See Blackburn, Ruling Passions (Oxford: Oxford University Press, 1998), p. 75.

7. Ibid., p. 79.

8. See Paul Horwich, Truth (Oxford: Blackwell, 1998).

9. See James Dreier, "Meta-ethics and the Problem of Creeping Minimalism,” Philosophical Perspectives, Vol. 18, No. 1 (2004): pp. 23-44.

10. Ibid., pp. 27-28. 
11. See Peter Geach, “Imperative and Deontic Logic,” Analysis, Vol. 18, No. 3 (1958): pp. 49-56; Geach, “Ascriptivism,” The Philosophical Review, Vol. 69, No. 2 (1960): pp. 221-225; Geach, “Assertion,” The Philosophical Review, Vol. 74, No. 4 (1965): pp. 449-465; John Searle, “Meaning and Speech Acts,” The Philosophical Review, Vol. 71, No. 4 (1962): pp. 423-432.

12. Geach, “Assertion,” p. 463.

13. See ibid., p. 449.

14. See Blackburn, Spreading the Word, pp. 189-196. See also Gibbard, Thinking How to Live (Cambridge, Mass.: Harvard University Press, 2003).

15. See Blackburn, Spreading the Word, p. 195.

16. See ibid., pp. 195-196.

17. See Mackie, op. cit, p. 35.

18. See David Hume, A Treatise of Human Nature, David Fate Norton and Mary J. Norton eds. (Oxford: Oxford University Press, 2000), p. 266.

19. See Shafer-Landau, op. cit., p. 125.

20. Ibid.

21. See ibid., pp. 125-127.

22. See Mackie, op. cit, p. 35; Joyce, op. cit., p. 9.

23. See Joyce, op. cit., p. 5.

24. See Mackie, op. cit., pp. 42-46.

25. See Mackie, op. cit., p. 43. 
26. I would like to thank two anonymous reviewers and the editor in chief, Thomas Magnell, for offering very helpful comments on this paper. I am indebted also to David Agler for providing careful and insightful commentary on an early draft. 